\title{
Studies in Sublittoral Ecology. I. A Submarine Gully in Wembury Bay, South Devon.
}

\author{
By
}

\author{
J. A. Kitching, B.A., Ph.D., \\ Lecturer in Zoology, Birkbeck College, London, \\ T. T. Macan, B.A., \\ Christ's College, Cambridge, \\ and \\ H. Cary Gilson, B.A., \\ Trinity College, Cambridge. \\ With 2 Figures in the Text.

\section{CONTENTS.}

1. InTRODUCTION

II. Apparatus and Methods . . . . 679

1. The Diving Helmet and Pumps . . . . . . . . . 679

2. The Telephone . . . . . . . . . . . . . . 679

3. Guide Ropes and Safety Lines . . . . . . . . . 680

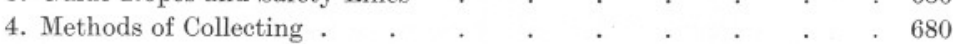

III. Description of Environment . . . . . . . . . 681

1. Geographical Account . . . . . . . . . . . . 681

2. Ecological Factors . . . . . . . . . . . . . $\quad .682$

IV. Distribution and Analysis of Types of Community . . . . 684

1. The Laminaria Forest Association ․ . . . . . . . 685

2. The Distomus-Halichondria Association . . . . . . . 687

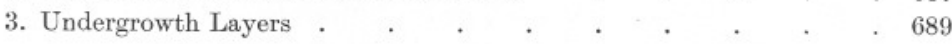

V. Analysis of Lists . . . . . . . . . . . . 691

1. Areas from Laminaria Forest Association . . . . . . 691

2. Areas from Distomus-Halichondria Association . . . . . 693

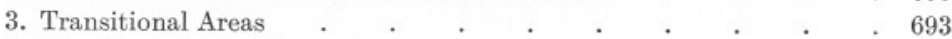

4. New Records for Plymouth . . . . . . . . . $\quad$. 693

VI. Discussion . . . . . . . . . . . . . . . $\quad .694$

SUMmary . . . . . . . . . . . . . . . . . 697

REFERENCES . . . . . . . . . . . . . 697

Appendix . . . . . . . . . . . . . . . . 698 


\section{INTRODUCTION.}

Вотн the intertidal region of the shore, and the sea-bottom at depths of anything over three or four fathoms, have been comparatively well explored biologically; but that part of the sea coast which lies just below the level of low water spring tides is - around the British Islesalmost unknown. It is out of range of ordinary shore-collecting, and yet much of it is also unsuitable for detailed investigation from a boat. This is especially true of steep, rocky shores, where a large part of the sublittoral region consists of ledges and vertical or even overhanging rock faces, which would be quite inaccessible even if work from a small boat were attempted. In Sweden Gislén (1930), who employed a professional diver, has made an extensive general survey of the plant and animal associations characteristic of a rocky bottom in the Gullmar fiord. But for the British Isles previous knowledge relates only to the distribution of the larger and more conspicuous algæ (Cotton, 1912); although the flora of the German warships which were sunk in Scapa Flow has been investigated more closely by Miss Lyle (1929), also with the help of a professional diver.

In the summer of 1931, at the suggestion of Mr. G. A. Steven, of the Plymouth laboratory of the Marine Biological Association, the writers decided to test the possibility of carrying out a detailed investigation of this hitherto unexplored region by means of a diving helmet (see below). Such a helmet has been used by many workers in the tropics, but has not previously been tried in temperate waters, in view of certain supposed difficulties. Chief of these were :-

(i) Water too cold for an unprotected diver.

(ii) Poor visibility.

(iii) Excessive interference by rough weather.

These difficulties were found to be either not effective, or else easily surmountable, and are discussed in detail below.

(i) Cold. In July and August near Plymouth we found that we could each stay down for about a quarter of an hour at a stretch fairly comfortably, and at most for twenty minutes. We compensated ourselves for this shortness of time below water by working as a team generally of four people, of whom each went down in his turn ; so that an hour's work could be done below water on any one day, and in favourable circumstances more. We found that the use of grease was of little help in combating the cold. Frequent diving led to a greatly increased appetite for sugar and treacle.

(ii) Visibility. There has always been plenty of light at the depths at which we have worked (down to six fathoms on the west coast of 
Scotland). After rough weather the water was often turbid with silt in suspension, but even so with a sandy* bottom it was always possible to see clearly objects not more than two feet away.

(iii) Rough weather. On shores open to the English Channel the helmet could only be used with safety when the sea was moderately calm. A heavy "ground" swell makes diving impossible, even though the water is otherwise smooth, as it breaks with violence on the rocks. For this reason on an Atlantic coast diving would be difficult, but might be done from a boat. We were able to work under water on about half of the number of days during which operations were in progress, but in settled summer weather it should be possible to dive every day.

In this paper are presented the results of an ecological survey of a small area on the coast near Plymouth, extending from Low Water of Ordinary Spring Tides down to a depth of about 10 feet below this level. The survey was carried out between July 14th and August 14th, 1931, and between July 1st and August 3rd, 1932.

\section{Apparatus and Methods.}

As the methods employed were modified to suit conditions in our seas, a moderately full account of them is given below.

\section{The Diving Helmet and Pumps.}

The helmet which we used is similar to that described and figured by Beebe (1926), with the difference that, on the advice of Professor C. M. Yonge, in order to avoid "seeing double," we had only one window. Such a helmet fits loosely over the diver's shoulders, and the pressure of air inside it, which is maintained from above by means of pumps (see below), keeps the water out. A helmet of this type is comparatively light and easy to handle, and below water it restricts the movements of the diver very little. It is therefore suitable for use when working in crevices and on steep rock faces. Further, its use requires no previous experience, and the diver, who is in no way attached to it, can easily leave it and swim to the surface if anything goes wrong.

A steady supply of air was provided for the diver from two foot motortyre pumps, which were connected through Schræder valves to a T-piece ; this last was connected through about 150 feet of garden hose with the helmet. One pump alone could in emergency supply sufficient air for the diver.

\section{The Telephone.}

A telephone system was installed, which enabled conversation to go on between the diver and those on shore. The system for speaking from the

* In a Scottish loch with a muddy bottom it was impossible to see at all once the mud was stirred up. 
shore to the diver consisted of an ordinary microphone and ear-phone circuit. But since carbon granule microphones are liable to give trouble if they get damp, a different system was used for speaking in the reverse direction. The diver spoke into a high-resistance ear-phone, which was connected at the land end through a transformer to a one-valve amplifier. The output from this was fed into a pair of wireless headphones. In order to keep out the sea-water, the ear-piece and acting microphone were each nearly filled with paraffin wax and covered with a thin rubber toy balloon.

\section{Guide Ropes and Safety Lines.}

(i) In order to recover the helmet should the diver find it necessary to leave it and come to the surface, and in order to take the weight of the helmet off the diver's shoulders while he was entering or leaving the water, a rope was attached to the top of the helmet itself.

(ii) A rope, securely belayed to the rock at its shore end, and attached to a fairly heavy stone at its free end, was thrown out in the direction in which the diver was intending to go. On this the diver lowered himself and hauled himself up. It also assisted him in finding his way to the required spot, and enabled him to work against a rock wall, suspended at any depth.

(iii) A third rope was used for lowering collecting bags to the diver.

\section{Methods of Collecting.}

It seemed essential that data should be quantitative. Accordingly, (a) complete collections were made of all animals and plants from small selected areas of rock surface; and $(b)$ observations were made of the general distribution of those types of biological community of which the areas were considered typical. In 1931 (July 14th-August 14th) the selected areas were scraped clean with a strong knife into jars. This was a very slow process, and great care was needed to avoid loss of material. Therefore in 1932 (July) we used large bags with folding metal frames in the mouths. These frames were 1 foot $\times 1$ foot or 2 feet $\times 1$ foot, and when closed could be clipped together so as to keep the bags shut. Areas were scraped into these with a paint-scraper. With each of these methods there were some fast-moving animals (e.g. prawns, small fish) which must have escaped; but as this work was directed mainly towards sedentary or slow-moving forms, which make up by far the greater part of the community, this does not matter much. Encrusting Coralline Algæ could seldom be scraped off the rock, and boring animals would not have been collected by this method, so that the collections must be considered incomplete in respect of these types. Although a standard size and shape of area would have been advantageous, we had in practice to take whatever areas were allowed by the configuration of the rock surface. 


\section{Description of Environment.}

1. Geographical Account.

The locality chosen for a detailed survey by means of diving was in Wembury Bay, South Devon; and the work was done in the gully on the S.E. side of the reef next to and S.E. of "Tomb Rock" (Ordnance Survey, 1913). This gully runs approximately N.E. and S.W., and is formed in the Dartmouth Slates (Ussher, 1912). It has on its N.W. side a nearly smooth rock wall, which is at about $15-20^{\circ}$ from the vertical,

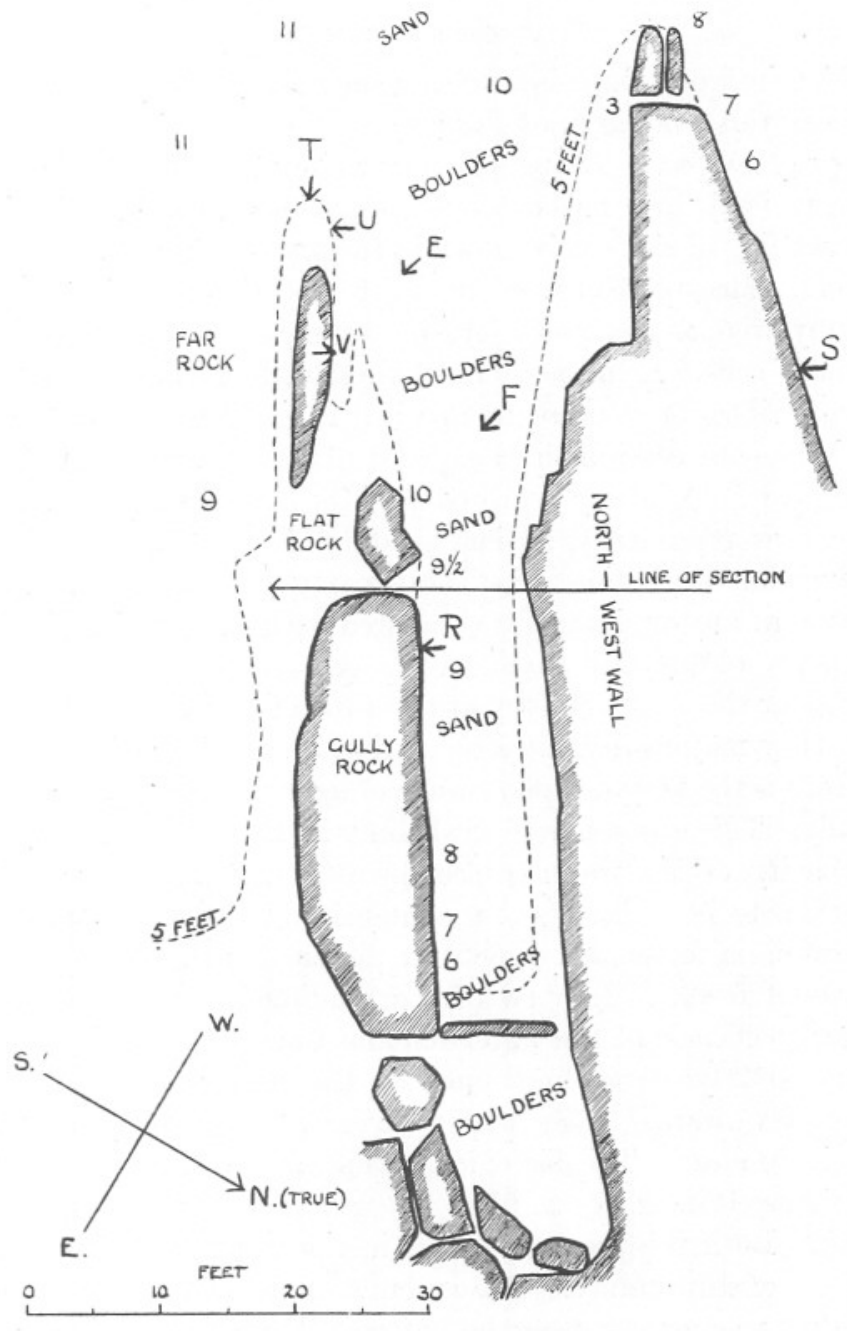

FIG. 1.-Chart of the Gully.

All depths are marked in feet below chart datum.

NEW SERIES.-VOL. XIX. NO. 2. MAY, 1934. 
facing upwards. On the S.E. side the rock surface is irregular and in most places overhanging (see section, Fig. 2). This gully is one of a series of similar parallel gullies which have been eroded in this particular way owing to the high angle of dip of the strata. The middle part of the gully (see Fig. 1) has a sandy bottom at a depth of 10 feet below the level of low water of ordinary spring tides. At the two ends of the gully the bottom is strewn with large boulders. At the S.W. end, beyond the boulders, the gully opens out to join the even sandy bottom which is characteristic of that part of Wembury Bay.

\section{Ecological Factors.}

The chief environmental influences which are likely to affect the flora and fauna of this gully are as follows :-

(i) Slope of Surface. This is believed to be of great biological importance (see p. 694), and has obvious connexions with illumination and with the settling of silt. It is shown in the section (Fig. 2).

(ii) Light. Measurements of the light intensity at various positions in the gully were made by Dr. Atkins by means of two cuprous oxide photoelectric cells. A full account of these cells, including the methods of use and the corrections to be applied, is given by Atkins and Poole (1933). While one cell remained exposed to the full light in air, the other was placed or held in any required position below water by the diver. The diver took precautions against shading his cell himself, and when it was in position he notified the shore party by telephone. Thus the illumination at any position was compared with that in air. A full table of the figures obtained is given in the Appendix. While such figures only represent the light intensity at one time of day and state of weather and tide, they may nevertheless be used as a basis for comparison. The chief feature is the very low percentage of light which reaches the bottom of the gully. This is due partly to shading by the gully walls, and partly to the opacity of the water, especially near the bottom. The lowest figure obtained-less than $1 \%$ of the intensity in air-was from a position in the Laminaria forest (see p. 685) at the base of the plants, below the "canopy" of fronds. In view of the shading by the gully walls, the absorption coefficient of the water remains uncertain, but in any case it must vary greatly, depending much on the roughness of the sea, and increasing downwards. The upper layers at high tide are probably comparatively clear. The biological significance of illumination in this gully is discussed later (see p. 694).

(iii) Silt. Both the presence of silt in the water, and the settling of silt, may be of importance. The amount of silt in the water was very variable, but was greater near the bottom. Sometimes the bottom foot of water was thick with seaweed remains. Silt carried along in the water 
by waves probably has a scouring action, especially near the bottom. The amount of silt which settles will depend partly on the slope of the rock surface, and partly on changes in the turbulence of the water.

N.W.

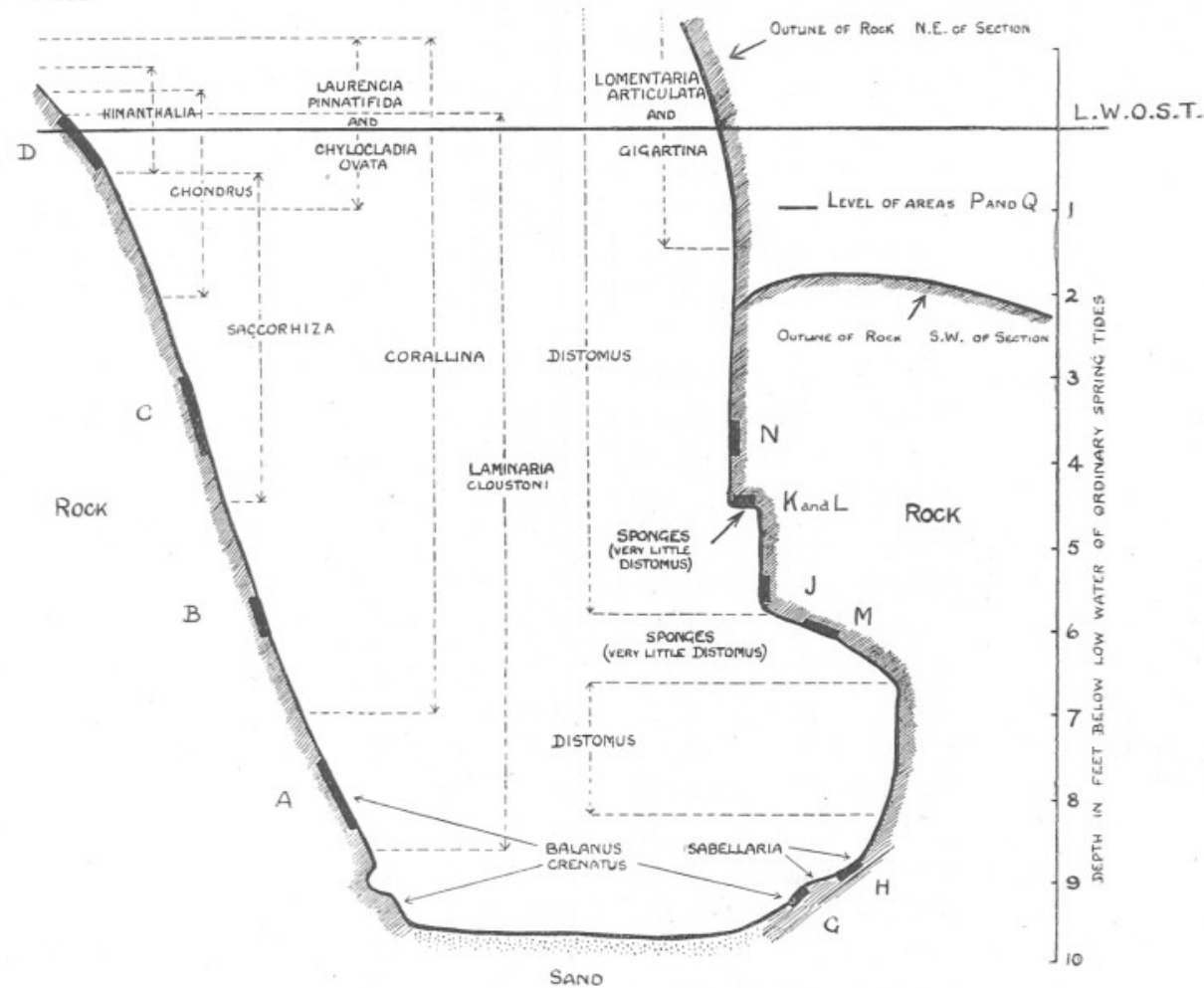

FIG. 2.- Section of the Gully.

L.W.O.S.T. Low Water of Ordinary Spring Tides has been taken as equal in level with Chart Datum. This latter was estimated by comparisons of the level of the water in calm weather with the level predicted for Devonport.

L.W.E.S.T. Low Water of Equinoctial Spring Tides is variable in level, but is generally between a half and two feet below Chart Datum.

We hope in a future investigation to be able to obtain some comparative measurements of the turbulence in different parts of the gully.

(iv) Wave action. This part of Wembury Bay is exposed* to weather

* Some indication is given of the degree of exposure to wave action by the fact that in the intertidal region Balanus balanoides, Chthamalus stellatus and Fucus vesiculosus evesiculosus are present,- the last in small patches only, and poorly grown; while Pelvetia, Fucus platycarpus and Ascophyllum are absent. This combination is indicative of moderate exposure. It is hoped that later it may be possible, at any rate on some parts of the coast, to use certain common intertidal plants and animals as indicators of the degree of exposure to waves of a locality. 
from S.W. by W. to S., and heavy storms occur in winter. It is possible that wave action is more intense on the N.W. wall than elsewhere, owing to the fact that waves rush up the intertidal slope above it, and then fall back with great force. It was observed during diving that the effects of a short choppy sea could scarcely be felt more than a few feet below the surface. But this part of the coast is much more subject to a comparatively long sea or swell, the influence of which extends to the bottom.

(v) Exposure to the air. This factor is not operative except in the intertidal region, which was studied in its lowest part only, merely for comparison with the contiguous infra-tidal region. Exposure to air may subject organisms both to desiccation and to rise in temperature.

(vi) Variations in oxygen-content of the water, and other chemical factors. These were not measured, as it is unlikely that areas in a region of so much water movement differ greatly in this respect. It is, however, possible that the fronds of the larger Algæ cause sufficient stagnation around their bases to produce an appreciable reduction in oxygen tension. It remains to be seen* to what extent the growth of various animals and plants upon the fronds and stipes of some of the larger algæ is to be ascribed to the presence of an environment more favourable than the rock surface itself (e.g. in oxygen tension, temperature, light, silt, turbulence), and to what extent it represents merely an overflow from the normal rock-surface community, induced by the struggle to gain a foothold.

(vii) Temperature. This rises near the surface on a calm warm day, but owing to unfavourable weather no adequate data were obtained. A discussion of this matter must therefore be withheld, although it is unlikely that temperature differences have any great significance.

\section{Distribution and Analysis of Types of Community.}

There were two main associations in the gully, the "Laminaria forest association " (including the "Laminaria association" and the "Himanthalia association" of Cotton (1912)) and the "Distomus-Halichondria association." In this description only the most important species are mentioned; many others occurred and are given in the full lists in the appendix. The nomenclature followed is for algæ that used by Newton (1931), and for animals that given in the Plymouth Marine Fauna (Marine Biological Association, 1931), unless it is stated otherwise.

* It is hoped to obtain data relating to this question during the course of a survey at present in progress on the W. coast of Scotland. A discussion of the influence of illumination on epiphytism is given by $\mathrm{B} /$ rgesen (1908). 


\section{The Laminaria Forest Association.}

This covered all the N.W. wall, and the boulders at the bottom of the gully. It occurred on all upward-facing rock surfaces in this and neighbouring gullies. When fully developed it consisted of :-

(a) A " canopy" layer formed by the fronds of one or more species of large brown alga (generally a Laminaria).

(b) An undergrowth of Corallina and other algæ.

(c) Species associated with the canopy.

(d) Species inhabiting the undergrowth and the holdfasts of the larger algæ.

\section{(a) The Canopy-forming Alga.}

Himanthalia lorea was dominant in a narrow belt about a foot wide around the level of low water-of ordinary spring tides. It occurred along the N.W. wall, on the E. side of "Gully" and "Far" rocks, and on the top of "Flat" rock (here above its more usual level). Corallina was present as a thick undergrowth. Himanthalia "buttons" were seen at lower levels, but never the reproductive parts. Laminaria Cloustoni was also present in this zone.

Saccorhiza bulbosa was dominant in 1931 in a belt just below the Himanthalia zone on the N.W. wall, and also on the boulders at the S.W. end of the gully. In $1932 *$ it was almost completely absent from the gully except at the mouth, its place as dominant being taken by Laminaria Cloustoni.

Laminaria digitata was confined to the top of Far Rock (at L.W.E.S.T. level) and to ledges at L.W.E.S.T. level on the E. side of Far Rock and at the seaward end of the N.W. wall.

Laminaria saccharina was dominant in a small patch on the S.W. boulders in 1932 .

Laminaria Cloustoni was dominant in all parts of the Laminaria forest association except for the above-mentioned places, and even in these (except for places occupied by Laminaria digitata) it was present. On the N.W. wall it was graded in size, being larger (up to 340 grams) near the top. Only small specimens (up to about 60 grams) were found near the bottom. On the boulders however it reached up to 280 grams or more ; and it was very large (up to 1800 grams) and covered with other growths (Distomus variolosus on the holdfast, Rhodymenia palmata, other red algæ and Sertularia operculata on the stipe) on the top of the narrow ridge N.W. of Far Rock.

\section{Desmarestia aculeata and Desmarestia ligulata occurred fairly plentifully}

* In 1933 (September) it was observed that Saccorhiza bulbosa had reappeared both on the boulders and on the N.W. wall. 
in 1931, but were scarce in 1932 . The former was most common on the N.W. wall at about 5 feet from the bottom, while the latter was commoner above this level.

(b) The Undergrowth.

Corallina spp. formed a dense growth all over the N.W. wall except at the bottom. (Upper limit, 1 foot above low water of ordinary spring tides and higher in cracks.) In places it was to some extent embedded in Halichondria panicea. From an examination of the samples collected, it appears that $C$. squamata predominated in the Himanthalia zone, but that lower down it was replaced by $C$. officinalis.

Chondrus crispus, Chylocladia ovata, and Laurencia pinnatifida were common in the zone of reproductive Himanthalia, and extended down to 1 or 2 feet below the bottom of this zone (see section). (Upper limit, 1 foot above L.W.O.S.T.) Gigartina stellata was locally plentiful in this zone.

Rhodymenia palmata was widely distributed (growing on the rock as well as on stipes of Laminaria Cloustoni).

Cladostephus verticillatus was locally abundant on the boulders.

(c) The Population of the Canopy Layer.

Rhodymenia palmata and Sertularia operculata grew on the stipes of the larger plants of Laminaria Cloustoni.

Obelia lucifera and Gibbula cineraria occurred on the fronds of some plants of Laminaria Cloustoni.

Patina pellucida (small* individuals only) occurred feeding on fronds and stipes of Laminaria spp., Saccorhiza, and Himanthalia.

Membranipora membranacea was nearly always present on fronds of Laminaria digitata, but only occasionally on those of L. Cloustoni.

(d) The Population of the Undergrowth.

Sessile forms (dealt with approximately in order from the rock outwards) included :-

An encrusting corralline alga forming a continuous coating over the tops of many of the boulders, and over the bottom of the N.W. wall. It may have extended upwards, but if so it was concealed by other growths.

Pomatoceros triqueter, widely distributed, and reaching as far as the upper limit of Corallina ; and Umbonula verrucosa, occasional. Both of these were fixed to the rock.

Balanus crenatus, at the bottom of both walls of the gully,--fixed to the rock.

* Large individuals were occasionally found inside cavities, which they had no doubt themselves eaten out, in the holdfasts of large plants of Laminaria Cloustoni. 
Hiatella arctica, at base of undergrowth and probably burrowing in the rock, but this was not observed.

Sabellaria spinulosa, occasional on the N.W. wall, but often filling the holdfasts of Laminaria Cloustoni growing on the boulders. On low horizontal ledges at the foot of the S.E. wall-ledges on which there were a few scattered and small plants of Laminaria Cloustoni-Sabellaria tubes formed a continuous coating to the rock.

Mytilus edulis (very small) and Heteranomia squamula on and among the undergrowth, but chiefly fixed to Laminaria holdfasts and Corallina.

Schizoporella hyalina, chiefly in small patches on holdfasts of Laminaria Cloustoni.

Membranipora pilosa, on holdfasts of Laminaria Cloustoni and on the fronds of red algæ.

The vegetative "buttons" of Himanthalia-which may be treated as part of the undergrowth-were always at least partly covered with Polyzoa (Schizoporella hyalina and Membranipora pilosa) on their undersides. On the other hand polyzoa and algæ were never found growing on the upper side of the "button," or on the fertile frond, of a healthy Himanthalia plant; although on one occasion a dead "button " was found to be covered all over with Membranipora pilosa.

Bunodactis verrucosa and Spirorbis borealis on Corallina.

Grantia compressa and Sycon coronatum attached to the undergrowth at random.

And motile forms :-

Nereis pelagica and Platynereis dumerili, the largest specimens being mostly inside holdfasts ; and many other Polychæta errantia.

Jassa spp.

Elasmopus rapax.

Eurystheus maculatus (in areas " $\mathrm{C}$ " and " $\mathrm{Z}$ " this occurred in considerable numbers inside the holdfasts of Saccorhiza bulbosa); and many other Amphipoda.

Amphipholis squamata.

\section{The Distomus-Halichondria Association.}

This covered those parts of the S.E. wall which were overhanging, and all overhanging walls in a neighbouring gully. It ranged upwards above the level of L.W.O.S.T. in places. It consisted of :-

(a) A carpet-like growth of Distomus variolosus or of various sponges.

(b) Certain species (chiefly red algæ) projecting through $(a)$ but with their bases embedded in it.

(c) Species living on or among the " carpet."

(d) Species associated with (b). 
(a) Carpet-forming species.

Distomus variolosus was dominant on vertical or slightly overhanging rock faces. It formed in many places a continuous sheet. (Upper limit, about $2 \frac{1}{2}$ feet above L.W.O.S.T.)

Stolonica socialis was locally dominant at the seaward end of "Far Rock" in the region of transition from the Distomus-Halichondria association to the Laminaria forest association.

Sponges became more important the more the rock face overhung. On surfaces at an inclination of about $60^{\circ}$ from the vertical, and facing downwards, sponges (especially Halichondria panicea, but also other species) were dominant, and Distomus was almost absent except where the inclined part adjoined a vertical Distomus-covered part.

(b) Projecting species.

Red algæ such as Rhodymenia Palmetta, Cryptopleura ramosum, and Myriogramme Bonnemaisoni were widespread below L.W.E.S.T. level on vertical or slightly overhanging surfaces, but they did not grow on the more steeply overhanging rock faces.

Gigartina stellata, Laurencia pinnatifida, and Lomentaria articulata were plentiful at and above the L.W.E.S.T. level, and in places grew thickly. (Upper limit $2 \frac{1}{2}-3$ feet above L.W.O.S.T.)

Hydroids, especially Aglaophenia pluma and Sertularia operculata, were common.

(c) The Population of the Sponge-Distomus " carpet."

Sessile species included:- -various Cirripedia, Umbonula verrucosa, Pomatoceros triqueter - all growing on the rock surface, and generally much overgrown. Pomatoceros triqueter was very common at about 1 to 2 feet above L.W.O.S.T., under overhanging rocks, and near the upper limit of the carpet-forming species. The upper limit was 3 feet above L.W.O.S.T.

Hiatella arctica, Sabella pavonina, Dasychone bombyx, and other Polychæta sedentaria embedded in the sponges or Distomus.

Corynactis viridis, commonest under shelves in the sponge-covered areas.

Mytilus edulis.

Heteranomia squamula.

And motile species :-

Many Polychæta errantia, including Nereis pelagica and Platynereis dumeriti.

Many Amphipoda, including Jassa spp., Elasmopus rapax, Apherusa jurinei, and various Caprellidæ.

Amphipholis squamata. 
(d) The Population of the Projecting species included :-

Membranipora pilosa, growing in great profusion on red algæ, especially on Gigartina stellata.

Schizoporella hyalina, also very plentiful on red algæ, especially on Rhodymenia Palmetta.

Parajassa pelagica, nesting in the branches of Sertularia operculata.

Caprellidæ.

\section{Undergrowth Layers.}

More detailed examination of the undergrowth of the two sides of the gully leads to the subdivision of that of the Laminaria forest association into :-

(i) Outer undergrowth layer, consisting of larger undergrowth algæ such as Rhodymenia palmata, Chondrus crispus, etc., and generally rather loosely packed or sparse.

(ii) A middle layer of Corallina and holdfasts of Laminaria, which is dense.

(iii) A basal layer of species which are completely adherent to the rock surface, such as Balanus crenatus, Pomatoceros triqueter, and Umbonula verrucosa.

The "carpet" layer of the Distomus-Halichondria association corresponds with the middle layer of the Laminaria forest undergrowth, and it is this layer which harbours most of the animal species. The projecting species of the Distomus-Halichondria association correspond with the outer layer of the Laminaria forest undergrowth ; this layer is generally populated chiefly by Polyzoa, and is too loosely packed to give shelter to many motile animals. This detailed analysis is summarised in Table I.

TABLE I.

\begin{tabular}{|c|c|c|c|}
\hline Layer. & $\begin{array}{l}\text { Fully developed } \\
\text { Laminaria forest } \\
\text { association. }\end{array}$ & $\begin{array}{c}\text { Distomus } \\
\text { sub-association. }\end{array}$ & $\begin{array}{l}\text { Halichondria } \\
\text { sub-association. }\end{array}$ \\
\hline Canopy & Present & None & None \\
\hline $\begin{array}{l}\text { Outer } \\
\text { Undergrowth }\end{array}$ & Present & Present & Reduced \\
\hline $\begin{array}{l}\text { Middle } \\
\text { Undergrowth }\end{array}$ & Present & Present & Present \\
\hline $\begin{array}{l}\text { Basal } \\
\quad \text { Undergrowth }\end{array}$ & Present & Present & Present \\
\hline
\end{tabular}




\section{TABLE II.}

Alt Quantities have been Reduced to Numbers per Square Foot.

\begin{tabular}{|c|c|c|c|c|c|c|c|c|c|c|c|c|c|c|c|c|c|c|c|}
\hline ฮึ่ & 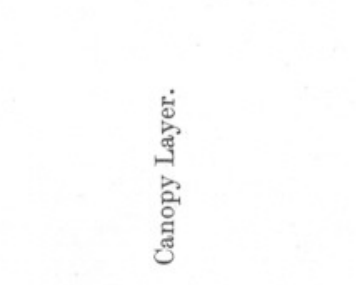 & 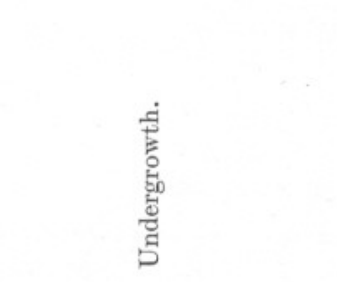 & 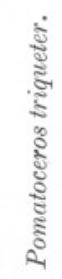 & 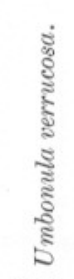 & 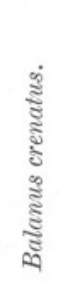 & 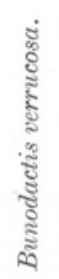 & 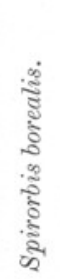 & 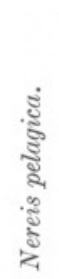 & 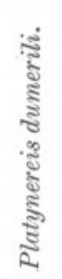 & 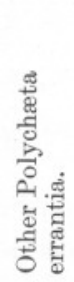 & 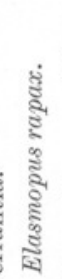 & 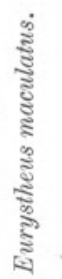 & 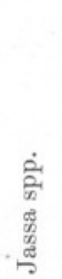 & 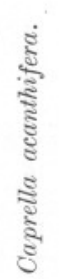 & 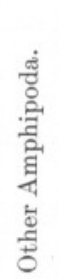 & 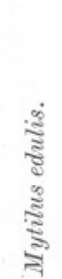 & 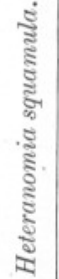 & 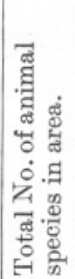 & 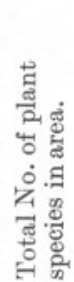 \\
\hline D & $\begin{array}{l}\text { Himanthalia (dominant). } \\
\text { Some Laminaria Cloustoni. }\end{array}$ & $\begin{array}{l}\text { Corallina, Chondrus, } \\
\text { Laurencia, Chylocladia. }\end{array}$ & 5 & $\begin{array}{l}\frac{3}{4} \text { to } \\
1 \text { sq. } \\
\text { in. }\end{array}$ & 0 & 54 & 49 & 11 & 0 & 10 & 3 & 0 & 2 & 0 & 2 & 216 & 16 & 26 & 8 \\
\hline $\mathrm{C}$ & $\begin{array}{l}\text { Saccorhiza (dominant). } \\
\text { Some Laminaria Cloustoni }\end{array}$ & $i$. Corallina. & 8 & 0 & 0 & 51 & 31 & 7 & 17 & 22 & 144 & 43 & 43 & 9 & 22 & 85 & 17 & 66 & 10 \\
\hline B & $\begin{array}{l}\text { Laminaria Cloustoni } \\
\text { (dominant). }\end{array}$ & Corallina (a little). & 17 & 0 & 14 & 31 & 12 & 5 & 2 & 22 & 0 & 0 & 0 & 0 & 12 & 804 & .5 & $26^{*}$ & $4^{*}$ \\
\hline A & $\begin{array}{l}\text { Very small plants of } \\
\text { Laminaria Cloustoni. }\end{array}$ & $\begin{array}{l}\text { Practically none (excluding } \\
\text { holdfasts). }\end{array}$ & 79 & $\begin{array}{l}1 \text { to } \\
2 \text { sq. } \\
\text { ins. }\end{array}$ & 872 & 0 & 0 & 12 & 2 & 5 & 0 & 0 & 5 & 2 & 6 & 265 & 17 & 30 & 4 \\
\hline
\end{tabular}

* These values are probably too low, as area B is smaller than the other areas. 


\section{Analysis of Lists.}

\section{Areas from Laminaria Forest Association.}

Areas A, B, C, D were taken from the N.W. wall. The basal part of the wall, from which Area A was collected, is very poorly illuminated (see Table VIII), and in the water around it there is much suspended matter, which probably has a scouring action. To one or both of these influences may be attributed the lack of undergrowth. The fauna of A differs from that of Areas B, C, D, which are higher up the wall, in the following respects (see Table II) :-

(i) Absence of Spirorbis borealis and Bunodactis verrucosa, which may be attributed to the absence of Corallina (or possibly to the presence of so much silt).

(ii) Abundance of Balanus crenatus and Pomatoceros triqueter, and

\section{TABLE III.}

\section{Species Confined to or Characteristic of the Laminaria Forest Association.}

Algæ.

Desmarestia aculeata.

Desmarestia ligulata.

Cladostephus verticil. latus.

Laminaria digitata.

Laminaria saccharina.

Laminaria Cloustoni

Saccorhiza bulbosa.
Himanthalia lorea.

Corallina officinalis.

Corallina squamata.

- Chylocladia ovata.

Cœlenterata.

$\dagger$ Obelia lucifera.

$\dagger$ Bunodactis verrucosa.

Polychæta.

$\uparrow$ Spirorbis borealis.
Crustacea.

Anthura gracilis.

Mollusca.

Paphia pullastra.

$\uparrow$ Patina pellucida.

†Gibbula cineraria.

Tricolia pullus.

And other rarer species.

\section{TABLE IV.}

\section{Species Confined to or Characteristic of the Distomus-Halichondria Association.}

Algæ.

Myriogramme Bonnemaisoni.

Rhodymenia Palmetta.

Lomentaria articulata.

Porifera.

Leucosolenia coriacea.

Leuconia nivea.

Leuconia gossei.

Amphilectus fucorum.

Myxilla rosacea.

Anchinoe fictitia.

Colenterata.

Myriothela cocksi.

Dynamena pumila.

Sertularella polyzonias.
Sertularia operculata.

Plumularia setacea.

Aglaophenia pluma.

Corynactis viridis.

Nemertini.

Erstedia nigra.

Polychæta.

Syllis prolifera.

Syllis variegata.

Eusyllis blomstrandi.

Sabella pavonina.

Dasychone bombyx.

Crustacea.

Verruca strœmia.

Balanus perforatus.

Stenothöe marina.
Nototropis swammerdami.

Lembos websteri.

Caprella acutifrons.

Caprella tuberculata.

Mollusca.

Kellia suborbicularis.

Bryozoa.

Schizoporella linearis.

Tunicata.

Distomus variolosus.

Amaroucium punctum.

Diplosoma listerianum.

And other rarer species. 


\section{TABLE V.}

\section{Species Common to Both Associations.}

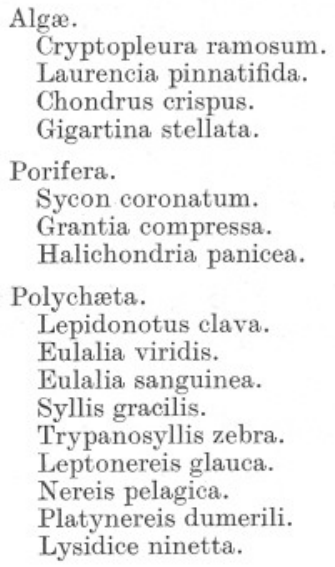

\author{
Sabellaria spinulosa. \\ Pomatoceros triqueter. \\ Crustacea. \\ Balanus crenatus. \\ Janira maculosa. \\ Lysianassa ceratina. \\ Apherusa jurinei. \\ Apherusa bispinosa. \\ Gammarellus angulosus. \\ Elasmopus rapax. \\ Microdeutopus sp. \\ Eurystheus maculatus. \\ Jassa falcata. \\ Jassa dentex. \\ Parajassa pelagica. \\ Unciola crenatipalma. \\ Caprella acanthifera. \\ Porcellana longicornis. \\ Pycnogonida. \\ Pycnogonum littorale.
}

presence of a considerable amount of Umbonula verrucosa. This is probably connected with the absence of undergrowth such as would cover them up. Area C, from the Saccorhiza zone, contains the largest number of animal species, and the largest numbers of individuals of most of the species.

Areas E, F, and Z were collected from the S.W. boulders, where the illumination is very poor under the Laminaria and Saccorhiza fronds (see Table VIII) and where there is at times a great amount of sediment and algal débris in the water. As in Area A, there is very little undergrowth, but Laminaria and Saccorhiza holdfasts, which function as undergrowth, are present. These areas are fairly poor in undergrowth inhabiting species, although the fauna is in most respects similar to that of B, C, D. The absence of Balanus crenatus is noticeable.

Areas $\mathrm{G}$ and $\mathrm{H}$ are from the base of the S.E. wall. Area $\mathrm{G}$ corresponds in position to some extent with Area A on the N.W. wall, and resembles it in its large number of Balanus crenatus. Area $\mathrm{H}$, from a flat sandy ledge near the bottom of the S.E. wall, contains many individuals of Sabellaria spinulosa.

A list of species confined or nearly confined to the Laminaria forest association is given in Table III. The only five animals (marked with daggers) on this list which are common are associated especially with algæ peculiar to the association. It is not surprising that of the species common to both associations (Table V), all belong to the undergrowth. 


\section{Areas from the Distomus-Halichondria Association.}

Areas $\mathrm{R}$ and $\mathrm{S}$ were collected about 1 foot above the level of L.W.O.S.T., and from their fauna it is clear that many species which are characteristic of the sub-littoral region extend upwards above the L.W.E.S.T. level on vertical or overhanging surfaces. These areas also contain several Tunicata which were not collected elsewhere. Apart from this a detailed study of the separate areas of this association does not reveal more than has already been noted in the preceding section from general observations.

Among the species confined to this association (see Table IV) the importance of Porifera, Colenterata, and Tunicata is remarkable,-and so in a lesser degree is that of Polychæta sedentaria, Cirripedia, and Caprellidæ.

\section{Transitional Areas.}

Areas $\mathrm{T}$ and $\mathrm{U}$ are to a large extent intermediate between the Laminaria forest and Distomus-Halichondria associations. Their fauna may be analysed as follows :-

\section{TABLE VI.}

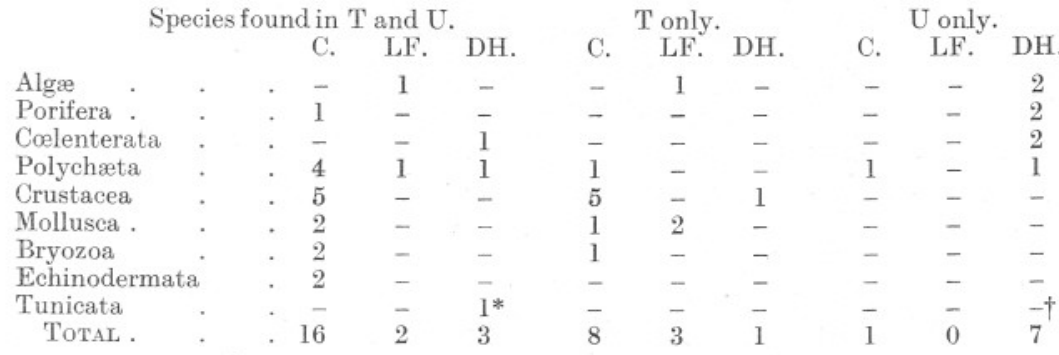

* Also one species found nowhere else.

$\uparrow$ Two species found nowhere else.

Column $\mathrm{C}=$ species common to both associations.

$\mathrm{LF}=$ species of the Laminaria forest group.

$\mathrm{DH}=$ species of the Distomus-Halichondria group.

Only species which occur in sufficient areas (i.e. at least two) and in sufficiently large quantities to be grouped in Tables III, IV and V have been considered in this analysis.

It will be seen that $U$ shows a marked predominance of species from the Distomus-Halichondria association, as compared with $\mathrm{T}$, which shows a less marked one of "Laminaria forest" species, and a great number of "common" species. A detailed study of the intermediate region might reveal an interesting transitional zonation, especially in the tunicates.

\section{New Records for Plymouth.}

Twelve animal species (see Table VII in the Appendix) were found which are not listed in the Plymouth Marine Fauna (Marine Biological 
Association, 1931), and of these six are Porifera from the overhanging S.E. wall. This is explained by the fact that hitherto such localities have been very difficult of accesis.

\section{Discussion.}

The differences between the various associations and sub-associations are so sharply marked, and show such close correlation with the differences in the external conditions of the habitat, as to suggest that the nature of these associations is rigorously controlled by environmental factors. The principal difference between the regions colonised by the two main associations is the slope of the rock surface, which will react on the fauna and flora in several ways, viz. :-

(i) Ability of spores or larvo to settle or develop.

It is possible that some spores or larvæ may be unable to settle on overhanging rock surfaces, or that such positions may be unsuitable for their further development into adult organisms. The possibility that some such unknown factor excludes the larger brown algæ* from overhanging surfaces must not be ignored. The fact that the areas scraped clear in 1931 were almost all unrecognisable in 1932 shows that no such difficulty operates against the dominant members of the DistomusHalichondria association, and that any given area continues to support a similar community even after such drastic interference. This was perhaps to be expected, since depopulation by storms must be a fairly frequent event.

(ii) Settling of silt.

It is noticeable that the most important of the species confined to the Distomus-Halichondria association are such as might be damaged by excessive deposition of silt. Unless they are excluded from the Laminaria forest association by competition or by some adverse effect of light, silt may be the responsible factor. It is possibly significant that whereas the stalked sponges were found plentifully on both walls of the gully, the encrusting species were confined to, or only flourished on the vertical or overhanging parts of the S.E. wall. The fact that hydroids were not found on the N.W. wall except on Laminaria fronds suggests that they may require to be held further off the rock face into a position where the water is more turbulent and silt-deposition less.

(iii) Illumination

Laminaria Cloustoni occurred, though poorly and sparsely, on the Sabellaria ledge ; but on the upper part of the S.E. wall-a position which

* Intertidally Pelvetia and Fucus platycarpus are usually absent from overhanging rock surfaces. 
is better illuminated (see Table VIII) - it did not grow at all. While its poorness of growth on the former may possibly have been due to a deficiency of light, its absence from the latter cannot be attributed to this cause. Unless Laminaria Cloustoni is unable to gain a foothold among or compete with the members of the Distomus-Halichondria association, its absence from the upper part of the S.E. wall must in some way be connected with the slope of the surface. The grading in size of Laminaria plants on the N.W. wall may be due to the greater illumination near the surface; they probably often get torn off by storms, and the Laminaria forest would be regenerated more quickly where the illumination was greater. But there may also be some adverse factor such as silt in suspension affecting those near the bottom. The absence of Saccorhiza bulbosa in 1932 may probably be attributed to its being torn off by storms. The Sabellaria ledge at the bottom of the S.E. wall may be regarded as potential Laminaria forest which has failed to develop properlypossibly owing to inadequate illumination.

Of the large brown algæ Saccorhiza bulbosa with its capacious holdfast supported by far the largest fauna, as regards both number of species and number of individuals ; these included not only many small forms such as amphipods and polychætes, but also small fish and young echinoderms. Laminaria Cloustoni had a moderate fauna; but Desmarestia spp. and Himanthalia, which have small holdfasts, were in this respect unimportant.

The same types of community which are found below the low water of equinoctial spring tides reach a little way above this level, especially under ledges where there is protection from the adverse effects of being left high and dry. Colman (1933) has pointed out that at any time the belt of sea-shore which is within reach of the splashing of waves may be considered as being, for biological purposes, submerged. Thus infra-tidal conditions extend upwards above the level of L.W.E.S.T. by the width of the "splash zone." Many species found at this level may be regarded as really belonging to the infra-tidal region, and as having ranged upwards as far as conditions have allowed. Certain algæ, on the other hand (notably Himanthalia and Laurencia), belong properly to the lowest part of the inter-tidal region, and do not flourish below it. It is possible that illumination is the limiting factor. Strong evidence has been brought forward by Gail (1918) that insufficient illumination limits the downward distribution of Fucus in Puget Sound.

The part played by the basal undergrowth layer (encrusting Coralline algæ, barnacles, Pomatoceros triqueter, and Umbonula verrucosa) is especially interesting. The occurrence of barnacles both in the intertidal region and at the bottom of the N.W. and S.E. walls suggests that they are only able to live where they are free from competition with 
various other species. They are able to endure conditions which other species cannot endure, but in open competition become overgrown and smothered. The same is probably true to a less extent of other species of the basal undergrowth layer. Pomatoceros occurred most plentifully at the bottom of the N.W. wall and on vertical or overhanging faces in the lowest part of the inter-tidal region (up to 3 feet above L.W.O.S.T.), near the upper limit of the distribution of the main carpet-forming species. Unlike the barnacles, it is prevented, no doubt by the effects of exposure to air, from colonising the corresponding inter-tidal levels on the upward facing N.W. wall. From the occurrence of barnacle remains under Distomus variolosus and other carpet-forming species, and from an examination of the fauna of Area $J(2)$, - an area which was scraped on the same site as the Area $J(1)$ of the previous year-it seems that Balanus crenatus is (at any rate in some cases) an early coloniser of any available space, but that it later succumbs owing to competition. Our inability in 1932 to find any trace of the previous year's scrapings shows that recolonisation is very rapid.

\section{ACKNOWLEDGEMENTS.}

This work was suggested to us by Mr. G. A. Steven, to whom we are grateful. We are indebted to Messrs. H. H. Brown and D. W. I. Piggott, who took part in the diving, to Mr. G. Williams of Warren Point for putting at our disposal accommodation for the storage of gear, to Dr. W. R. G. Atkins for making the measurements of light intensities, to Professor H. G. Jackson in whose department much of the work was done, to Dr. Allen, and to many members of the Plymouth Laboratory Staff. Acknowledgements are also due to the following experts who identified many of the specimens :-Dr. R. Bassindale (Cirripedia), Mr. M. Burton (Porifera), Miss C. I. Dickinson (many Algæ), Mr. W. Edgar Evans (Zoantharia), Professor H. G. Jackson (certain Isopoda), Mr. J. W. S. Pringle (many of the Amphipoda), Mr. J. E. Smith (most of the Tunicata), Mr. G. A. Steven (certain Amphipoda, Mollusca, Bryozoa, and others), and Mr. D. P. Wilson (certain Polychæta). (The remaining specimens were identified by ourselves as follows :- most Polychæta by H. C. G., most of the Algæ by T. T. M., the remaining material by J. A. K.) We are indebted to Dr. M. Knight for advice concerning the Algæ, and again to Professor H. G. Jackson and Mr. G. A. Steven for revising the manuscript. 


\section{SUMMARY.}

1. A diving helmet can be used successfully on British coasts.

2. An ecological survey, extending to a depth of 10 feet below low water of ordinary spring tides, has been made of a small area in Wembury Bay, S. Devon.

3. Below low water of ordinary spring tides upward facing rock surfaces were occupied by a " Laminaria forest association."

4. Below L.W.O.S.T. vertical or overhanging rock surfaces were occupied by a "Distomus-Halichondria association."

5. Large brown Algæ are excluded from the Distomus-Halichondria association by some factor connected with the slope of the rock surface, other than inadequate illumination.

6. Freedom from silt deposition may be responsible for many of the peculiarities of the Distomus-Halichondria association,-in particular for the importance of sponges, cœlenterates, and tunicates.

7. Barnacles play an important part in the recolonisation of bare rock surfaces.

\section{REFERENCES.}

Atkins, W. R. G., and Poole, H. H. 1933. The Use of Cuprous Oxide and other Rectifier Photo Cells in Submarine Photometry. Journ. Mar. Biol. Assoc., N.S., Vol. XIX, pp. 67-72.

Barnard, K. H. 1925. A Revision of the Family Anthuridæ. J. Linn. Soc. Zool., Vol. XXXVI, p. 140.

Befbe, W. 1926. The Arcturus Adventure. New York.

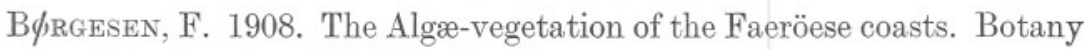
of the Faeröes, Vol. III. London.

Bowerbank, J. S. 1874. A Monograph of the British Spongiadæ. Vol. III, pp. 1-367. Ray Society, London.

Chevreux, E., et Fage, L. 1925. Amphipodes. Faune de France, Vol. 9, pp. 1-488.

Collinge, W. E. 1917. A Revision of the British Idoteidæ. Trans. Roy. Soc. Edin., Vol. LI. p. 742.

Colman, J. 1933. The Nature of the Intertidal Zonation of Plants and Animals. Journ. Mar. Biol. Assoc., N.S., Vol. XVIII, pp. 435-476.

Cotron, A. D. 1912. Clare Island Survey. Algæ. Proc. Roy. Irish Acad., Vol. XXXI. 
Fauvel, P. 1923, 1927. Polychètes errantes; Polychètes sédentaires. Faune de France, Vol. 5, 1923, pp. 1-488; and Vol. 16, 1927, pp. 1-494.

GaIL, F. W. 1918. Some Experiments with Fucus to determine the factors controlling its vertical distribution. Publ. Puget Sound Biol. Station, Vol. II, pp. 139-151.

Gislén, T. 1930. Epibioses of the Gullmar Fjord. Kristinenbergs Zoologiska station, 1877-1927. Upsala.

Lebour, M. V. 1933. The British species of Trivia. Journ. Mar. Biol. Assoc., N.S., Vol. XVIII, pp. 477-484.

Lyle, L. 1929. Marine Algæ on some German Warships in Scapa Flow and of Neighbouring Shores. J. Linn. Soc. Bot., Vol. XLVIII.

Marine Biological Association. 1931. Plymouth Marine Fauna. Plymouth.

Newton, L. 1931. A Handbook of the British Seaweeds. London.

Ordnance Survey. 1913. Scale $\frac{1}{2500}$. Devonshire, Sheet CXXX, 6 . Southampton.

Sars, G. O. 1899. An Account of the Crustacea of Norway. Vol. II, Isopoda, pp. 1-270.

Schmidt, O. 1864. Supplement der Spongien des Adriatischen Meeres, pp. 1-48. Leipzig.

Ussher, W. A. E. 1912. The Geology of the Country around Ivybridge and Modbury. Memoirs of the Geological Survey, England and Wales. London.

\section{APPENDIX.}

The following is a list of species recorded here for the first time at Plymouth :-

\section{TABLE VII.}

\section{Porifera.}

Leuconia nivea Grant [Bowerbank, 1874, 3, p. 11]

LeUCONIA Gossei (Bowerbank) [Bowerbank, 1874, 3, p. 13]

Ute GLABRA (Schmidt) [Schmidt, 1864, p. 23] . .

HaLICHONDRIA ALBESCENS (Bowerbank) (Bowerbank, 1874,3, p. 265] . . . . . . .

AMpHILCTUS FUCORUM (Johnston) [Bowerbank, 1874, 3, p. 142] · . . . . . . .

ANCHINOE FICTITIA (Bowerbank) [Bowerbank, 1874, 3, p. 265] .
Examined by

M. Burton

M. Burton

M. Burton

M. Burton

M. Burton

M. Burton
Area of occurrence. K, L, M, U.

M, S, U. I.

K.

M, R,S.

K, P, V. 
Polycheta. Examined by

Syllis (Ehlersia) FERrdgina (Langerhans) [Fauvel, 1923 , p. 269] . . . . . . . . Heterocirrus bioculatus (Keferstein) [Fauvel, 1927, p. 96] . . . . . . . . .

ISOPODA.

Heterotanais SP. ? Örstedi Kröyer [Sars, 1899, p. 14] Cyathura carinata (Kröyer) [Barnard, 1925, p. 140] . IDOTEA granulosa Rathke [Collinge, 1917, p. 742]

AMPHIPODA.

Gamiarellus angulosus (H. Rathke) [Chevreux et Fage, 1925, p. 204]

N.B.-Details concerning the areas of occurrence are given in Table IX.
Area of occurrence.

D. P. Wilson E, K.

D. P. Wilson J(1),

H. G. Jackson U.

H. G. Jackson S.

H. G. Jackson R.

B, Q, T, S.

\section{Measurements of Light Intensity.}

The following measurements of light intensities were made on August 3rd, 1932, between 12 noon and 1 p.m., G.M.T., and the under-water values are expressed as percentages of the illumination in air. The illumination in air varied from $40 \cdot 0$ to $127 \mathrm{k}$.m.c. (thousands of metrecandles). In cases when the sun was shining an approximate correction $\left(\times \frac{\text { total light }}{\text { diffuse light }}\right)$ has been applied, owing to the fact that the walls of the gully shaded the gully from direct sunlight. By means of this correction the under-water values are expressed as percentages of the diffuse light, and such corrected figures are shown in the table in brackets. The water was 12 feet deep when the measurements were made. The submarine photometer was held facing away from the rock, in such a way as to receive the maximum illumination.

\section{TABLE VIII.}

Illumination
in air illumination

\section{Position.}

Just below surface

$\begin{array}{cc}\text { (k.m.c.). } & \text { (k.m.c). } \\ 44 \cdot 4 & 29 \cdot 0 \\ 40 \cdot 9 & 8 \cdot 10-15 \cdot 2 \\ 50 \cdot 0 & 10 \cdot 8-18 \cdot 9 \\ 122 & 1 \cdot 36 \\ 127 & 15 \cdot 2-18 \cdot 3 \\ 127 & 6 \cdot 49 \\ 57 \cdot 7 & 1 \cdot 36 \\ 55 \cdot 5 & 1 \cdot 60 \\ 88 \cdot 9 & 2 \cdot 18 \\ 57 \cdot 7 & 1 \cdot 40 \\ 40 \cdot 0 & 1 \cdot 49 \\ 39 \cdot 7 & 0 \cdot 65 \\ 38 \cdot 5 & 3 \cdot 24 \\ 38 \cdot 9 & 1 \cdot 60-3 \cdot 77\end{array}$

N.W. wall, just below Himanthalia zone .

N.W. wall just below Himanthalia zone .

N.W. wall, bottom .

Middle of gully, $6 \mathrm{ft}$. above bottom

Middle of gully, $3 \mathrm{ft}$. above bottom .

S.E. wall, bottom

S.E. wall, bottom . . . . . 88.9

S.E. wall, Sabellaria ledge (Area $\mathrm{H})$. $\quad$. $\quad 57 \cdot 7$

S.E. wall, Area J . . . . . . $40 \cdot 0$

S.E. wall, Area K . $\quad 39 \cdot 7$

S.E. wall, Area N . $\quad . \quad$. $\quad . \quad . \quad . \quad 38.5$

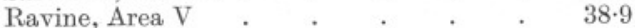

S.W. boulders, Laminaria forest, above fronds

$40 \cdot 8$

$2 \cdot 18$

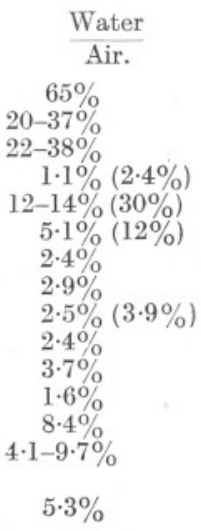

S.W. boulders, Laminaria forest, below fronds

$42 \cdot 2$

$0 \cdot 27-0 \cdot 44 \quad 0 \cdot 64-1 \cdot 0 \%$ 


\title{
TABLE IX.
}

\section{List of Sample Areas.}

\author{
Depth \\ above ( + ) \\ or below (-
}

$\begin{array}{ccc}\text { Dimensions L.W.O.S.T. } & \text { Date of } \\ \text { Area. } & \text { in inches. in feet. } & \text { Slope of Surface. }\end{array}$

\begin{tabular}{|c|c|c|c|c|c|}
\hline A & $12 \times 15$ & -8 & $60-70^{\circ}$ from & $\begin{array}{l}\text { near bottom of N.W. } \\
\text { wall }\end{array}$ & Aug. 3, 1931 \\
\hline B & $6 \times 10$ & -6 & horizontal, facing & on N.W. wall & Aug. 3, 1931 \\
\hline $\mathrm{C}$ & $12 \times 14$ & $-3 \frac{1}{2}$ & upwards & on N.W. wall & Aug. 4, 1931 \\
\hline D & $8 \times 11$ & 0 & & on N.W. wall & Aug. 7,1931 \\
\hline $\mathrm{E}$ & $\begin{array}{l}\text { Two separate } \\
\text { squares each }\end{array}$ & & & & \\
\hline & $12 \times 12$ & -10 & horizontal & on S.W. boulders & July 16,1932 \\
\hline $\mathrm{F}$ & $15 \times 15$ & -10 & horizontal & on S.W. boulders & July 18, 1932 \\
\hline $\mathrm{G}$ & $4 \times 4$ & $-9 \frac{1}{2}$ & $\begin{array}{l}40^{\circ}-50^{\circ} \text { from } \\
\text { horizontal }\end{array}$ & $\begin{array}{l}\text { at base of S.E. wall, } \\
\text { in section }\end{array}$ & Aug. 12, 1931 \\
\hline $\mathrm{H}$ & $6 \times 10$ & -9 & nearly horizontal & $\begin{array}{l}\text { on Sabellaria ledge, } \\
\text { in section }\end{array}$ & Aug. 7, 1931 \\
\hline$J(1)$ & $6 \times 9$ & $-5 \frac{1}{2}$ & vertical & $\begin{array}{l}\text { on S.E. wall, in } \\
\text { section }\end{array}$ & Aug. 7, 1931 \\
\hline$J(2)$ & $4 \times 4$ & $-5 \frac{1}{2}$ & vertical & on same site as $\mathrm{J}(1)$ & July 18,1932 \\
\hline K & $5 \times 14$ & $-4 \frac{1}{2}$ & $\begin{array}{l}\text { horizontal, facing } \\
\text { downwards }\end{array}$ & $\begin{array}{l}\text { on } \mathrm{S} \mathrm{E} \text { wall, in } \\
\text { section }\end{array}$ & Aug. 9,1931 \\
\hline L & $2 \frac{1}{2} \times 5$ & $-4 \frac{1}{2}$ & $\begin{array}{l}\text { horizontal, facing } \\
\text { downwards }\end{array}$ & close to L & Aug. 9, 1931 \\
\hline M & $6 \times 20$ & -6 & $\begin{array}{l}\text { overhanging, at } \\
\text { about } 40-50^{\circ} \\
\text { from vertical }\end{array}$ & $\begin{array}{l}\text { on S.E. wall, in } \\
\text { section }\end{array}$ & July 18,1932 \\
\hline $\mathrm{N}$ & $5 \times 9$ & $-3 \frac{1}{2}$ to -4 & vertical & $\begin{array}{l}\text { on S.E. wall, in } \\
\text { section }\end{array}$ & Aug. 13, 1931 \\
\hline$P$ & $9 \times 8$ & -1 & vęrtical & $\begin{array}{l}\text { at S.W. end of Gully } \\
\text { Rock, in section }\end{array}$ & Aug. 13, 1931 \\
\hline$Q$ & $2 \frac{1}{2} \times 4$ & -1 & vertical & close to $\mathrm{P}$ & Aug. 13, 1931 \\
\hline $\mathrm{R}$ & $12 \times 12$ & +1 & vertical & $\begin{array}{l}\text { on Gully Rock, facing } \\
\text { N.W., in Gully }\end{array}$ & July 7,1932 \\
\hline S & $12 \times 12$ & +1 & $\begin{array}{l}\text { overhanging at } \\
\text { about } 40-50^{\circ} \\
\text { from vertical }\end{array}$ & $\begin{array}{l}\text { in next gully, see } \\
\text { chart }\end{array}$ & July 18, 1932 \\
\hline $\mathrm{T}$ & $12 \times 12$ & -7 & nearly vertical & $\begin{array}{l}\text { at S.W. end of Far } \\
\text { Rock }\end{array}$ & July 23,1932 \\
\hline$U$ & $12 \times 12$ & -7 & vertical & $\begin{array}{l}\text { near S.W. end of Far } \\
\text { Rock }\end{array}$ & July 16, 1932, \\
\hline $\mathrm{V}$ & $10 \times 10$ & -4 & vertical & $\begin{array}{l}\text { inside vertical cleft, } \\
\text { about } 3 \text { feet wide, on } \\
\text { N.W. side of Far } \\
\text { Rock }\end{array}$ & Aug. 2, 1932 \\
\hline $\mathrm{Z}$ & - & -10 & horizontal & $\begin{array}{l}3 \text { plants of Saccorhiza } \\
\text { bulbosa, collected in } \\
\text { a bag }\end{array}$ & Aug. 7, 1931 \\
\hline
\end{tabular}

N.B.-The depths are taken to the middle of the Areas. 


\section{NOTES TO TABLES $\mathrm{X}$ AND $\mathrm{XI}$.}

In Tables $\mathrm{X}$ and $\mathrm{XI}$ the following abbreviations and signs have been used :-

fr. = fragment.

indiv. =individual.

s.q. = small quantity.

(?) identification not absolutely certain, owing to inadequacy of specimen.

(a) 13 of them very small.

(b) mostly Corallina squamata.

(c) quantity approximate.

(d) from holdfast of Saccorhiza bulbosa.

(e) on Corallina.

(f) +1 dead one.

(g) +2 dead ones.

(h) family inside Verruca stromia.

(j) a few small colonies.

(k) degenerating.

(1) breeding.

(m) probably Dendrodoa grossularia.

(n) breeding in July, 1931.

(p) 1 \% was also found intertidally on Gully Rock.

(q) 38 of them from holdfast of Saccorhiza bulbosa.

(r) $=7$ or 8 plants.

(s) small specimen or specimens.

(t) for nomenclature see Lebour (1933).

(u) O.lucifera includes 0 . dichotoma and 0 . geniculata in the Plymouth Marine Fauna.

(v) on Gigartina stellata.

(x) frond not collected.

The quantities of most Porifera have been estimated by volume (after preservation in alcohol). Rough plasticine models were made of the sponges, and the volumes of water displaced by the models were found. It is recognised that the sponges may have shrunk in the preservative.

Ectocarpus tomentosus Ectocarpus sp. Desmarestia aculeata Desmarestia ligulata Cladostephus verticillatus Laminaria saccharina. Laminaria Cloustoni Laminaria Cloustoni Dictyota dichotoma Dictyota dichotom

Fucus serratus ${ }^{\text {Himanthalia lorea (fertile) }}$ Himanthalia lorea (sterile) Lithophyllum incrustans Corallina officinalis

Corallina squamata

Delesseria sanguinea

Delesseria sanguinea

Myriogramme Bonnemaisoni

Phycodrys rubens

Polyneura Gmelini

Cryptopleura ramosum.

Laurencia pinnatifida

\section{TABLE $\mathrm{X}$.}

\section{Areas from "Laminaria Forest" Association.}

\begin{tabular}{|c|c|c|c|c|c|c|c|c|c|c|c|}
\hline \multirow{5}{*}{$\begin{array}{l}\text { Unit } \\
\text { measured. } \\
\text { plant } \\
\text { plant }\end{array}$} & \multirow[b]{2}{*}{ A } & \multirow[b]{2}{*}{ B } & \multirow[b]{2}{*}{ C } & \multirow[b]{2}{*}{ D } & \multirow[b]{2}{*}{$\mathbf{E}$} & \multirow[b]{2}{*}{ F } & \multirow[b]{2}{*}{ G } & \multirow[b]{2}{*}{ H } & \multicolumn{3}{|c|}{$\begin{array}{c}\text { Transitional } \\
\text { Areas. }\end{array}$} \\
\hline & & & & & & & & & $\mathrm{Z}$ & $T$ & $\mathbf{U}$ \\
\hline & - & - & - & - & 1 & - & - & - & - & - & - \\
\hline & - & - & - & - & - & 1 & - & - & - & - & - \\
\hline & - & - & - & - & fr. & - & - & - & - & - & - \\
\hline & - & - & - & - & fr. & - & - & - & - & - & - \\
\hline plant & - & 2 & - & - & - & - & - & - & - & - & - \\
\hline plant & - & $1(\mathrm{~s})$ & 1 & - & - & 7 & - & - & - & - & - \\
\hline plant & $7(\mathrm{~s})$ & 5 & $4(x)$ & $2(x)$ & 22 & $5(8)$ & - & - & - & - & - \\
\hline plant & - & - & $1(x)$ & - & 1 (s) & - & - & - & 3 & - & - \\
\hline frond & - & - & - & - & - & 1 & - & - & - & - & - \\
\hline plant & - & - & 1 (?) & - & - & $1(\mathrm{~s})$ & - & - & - & - & - \\
\hline plant & - & - & - & 8 & - & - & - & - & - & - & - \\
\hline plant & - & - & 5 & 7 & - & - & - & - & - & - & - \\
\hline sq. ins. & - & $\overline{-}$ & $i(c)$ & $2-3$ & - & - & - & - & - & - & - \\
\hline gram & - & 5 & 13 & 35 (b) & $\{1$ & - & - & - & - & 9 & $2(?)$ \\
\hline gram & - & - & 13 & $35(D)$ & $1-$ & - & - & - & - & - & - \\
\hline frond & $1(\mathrm{~s})$ & - & - & - & - & - & - & - & - & - & - \\
\hline plant & - & - & - & - & - & 1 & - & - & - & - & - \\
\hline & - & - & - & - & - & - & - & s.q.(s)(?) & - & - & fr. \\
\hline frond & - & - & - & - & 1 & 6 & - & - & - & - & - \\
\hline frond & - & - & - & - & - & - & - & 3 (?) & - & - & - \\
\hline frond & - & - & 4 & - & - & - & - & 2 & - & 8 & 3 \\
\hline frond & - & - & - & 5 & - & - & - & - & - & - & - \\
\hline
\end{tabular}




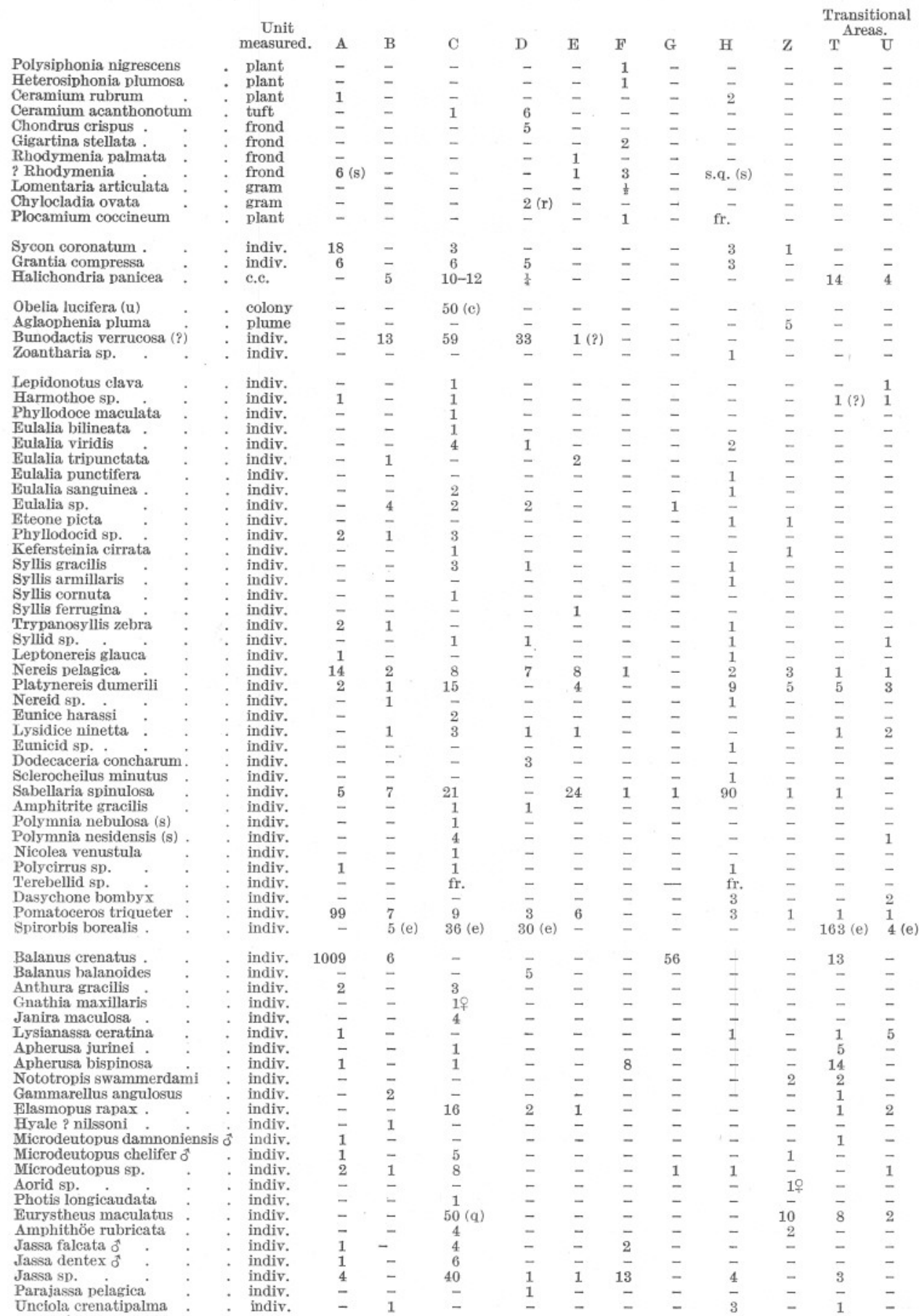




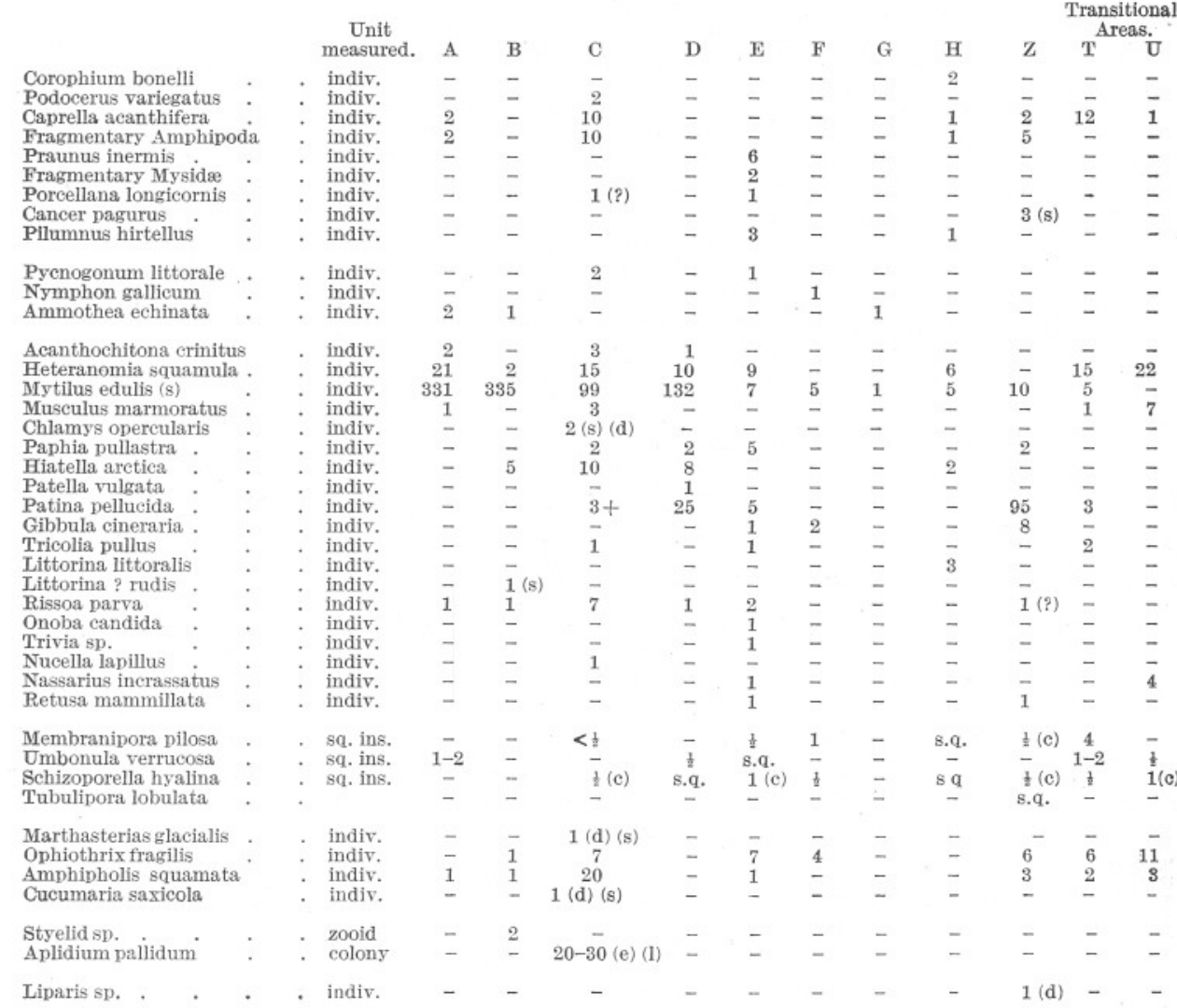

Transitional Areas (continued from above)

\begin{tabular}{|c|c|c|c|c|}
\hline $\begin{array}{l}\text { Laminaria sp. } \\
\text { Cystoclonoum purpu } \\
\text { Rhodymenia Palmet }\end{array}$ & ureum & $\begin{array}{l}\text { plant } \\
\text { plant } \\
\text {. } \\
\text { frond }\end{array}$ & $\begin{array}{l}\mathrm{T} \\
2(8) \\
1 \\
-\end{array}$ & $\begin{array}{l}\mathrm{U} \\
\overline{-} \\
\overline{3}\end{array}$ \\
\hline $\begin{array}{l}\text { Leuconia nivea. } \\
\text { Leuconia gossei } \\
\text { Halisarea dujardini }\end{array}$ & : & $\begin{array}{l}\text { c.c. } \\
\text { : c.c. } \\
\text { c.c. }\end{array}$ & $\begin{array}{l}- \\
-\end{array}$ & $\begin{array}{c}5 \\
1-2 \\
1\end{array}$ \\
\hline $\begin{array}{l}\text { Myriothela cocksi } \\
\text { Sertularella polyzoni } \\
\text { Corynactis viridis }\end{array}$ & & $\begin{array}{l}\text { indiv. } \\
\text { colony } \\
\text { indiv. }\end{array}$ & $\overline{-}$ & $\begin{array}{l}1 \\
1 \\
2\end{array}$ \\
\hline $\begin{array}{l}\text { Harmothŏe impar } \\
\text { Lumbriconereis sp. } \\
\text { Sabella pavonina }\end{array}$ & : & $\begin{array}{l}\text { indiv. } \\
\text { indiv. } \\
\text { indiv. }\end{array}$ & $\overrightarrow{\overline{1}(\mathrm{~s})}$ & \\
\hline Heterotanais? örsted & & . indiv. & - & 1 \\
\hline
\end{tabular}

Synisoma lancifer . . indiv.

Aora typica indiv.

Plonexes gammaroides . indiv.

Hippolyte varians . " indiv.

Trivia aretica $(\mathrm{t})$. . , indiv.

Goniodoris nodosa : : indiv.

Scrupocellaria reptans . colony Bugula turbinata . . colony

Polycarpa sp. . . . zooid

Styelid sp. ? Dendrodoa

Stolonica socialis

zooid

zooid

$$
\begin{array}{cc}
T & \text { U } \\
1 \sigma(\mathrm{p}) & - \\
2 & - \\
1 & - \\
2 & - \\
- & 1 \\
2(\mathrm{~s}) & 1 \\
- & 100(\mathrm{c}) \\
2 & - \\
- & 2 \\
- & 8 . q . \\
55(\mathrm{c}) & 200(\mathrm{c}) \\
100(\mathrm{c}) & 100(\mathrm{c})
\end{array}
$$


TABLE XI.

Areas from Distomus-Halichondria Association.

\begin{tabular}{|c|c|c|c|c|c|c|c|c|c|c|c|c|}
\hline & $\begin{array}{l}\text { Unit } \\
\text { measured. }\end{array}$ & $\mathbf{J}(1)$ & $\mathbf{J}(2)$ & $\mathbf{K}$ & L & M & $\mathrm{N}$ & $\mathrm{P}$ & Q & $\mathrm{R}$ & s & v \\
\hline Dictyota dichotoma & . frond & - & - & - & - & - & - & - & 20 & $0(\mathrm{c})(\mathrm{s})$ & 2 & - \\
\hline Corallina offlcinalis & . gram & - & - & - & - & - & - & - & - & - & - & 2 (?) \\
\hline Corallina squamata : & . gram & - & - & - & - & - & - & - & - & 3 & 1 & \\
\hline $\begin{array}{l}\text { Nitophyllum punctatum } \\
\text { Myriogramme }\end{array}$ & in frond & - & - & - & - & - & - & - & - & - & - & 3 \\
\hline $\begin{array}{l}\text { Myriogramemaisoní } \\
\text { Bonnemais }\end{array}$ & frond & - & - & - & - & - & - & - & - & - & 5 & 3 \\
\hline Cryptopleura ramosum & frond & - & - & - & - & - & - & - & - & - & - & 1 \\
\hline Laurencia pinnatifida. & frond & - & - & - & - & - & - & - & - & 40 (c) & - & - \\
\hline Pterosiphonia parasitica & plant & - & - & - & - & - & - & - & - & - & 1 & - \\
\hline Brongniartella byssoides & es plant & - & - & - & - & - & - & - & - & 1 & - & - \\
\hline Heterosiphonia plumosa & a plant & - & 1 & - & - & - & - & - & - & - & - & - \\
\hline Halurus equisetifolius . & . plant & - & - & - & - & - & - & - & 1 & - & - & - \\
\hline Ceramium circinatum. & . plant & - & - & - & - & - & - & s.q. & 1 & - & - & - \\
\hline Ceramium echionotum. & . plant & - & - & - & - & - & - & - & 1 & - & - & - \\
\hline Chondrus crispus & . frond & - & - & - & - & - & - & $12(\mathrm{~s})(?)$ & - & - & - & - \\
\hline Gigartina stellata . & - frond & - & - & - & - & - & - & $5(s)$ & $50(\mathrm{c})$ & 1 & - & $\overline{10}$ \\
\hline Phyllophora epiphylla. & . frond & $\overline{-}$ & - & - & - & - & $\overline{0}$ & - & - & - & - & 12( \\
\hline Rhodymenia Palmetta & frond & 16 & - & - & - & - & $9(?)$ & - & - & - & - & 3 \\
\hline Rhodymenia & . frond & - & 5 (s) & - & - & - & - & - & - & - & - & - \\
\hline Lomentaria articulata & gram & - & - & - & - & - & - & fr. & - & $75(\mathrm{c})$ & 1 & $\bar{z}$ \\
\hline Plocamium coccineum . & - plant & - & - & - & - & - & - & - & - & - & - & 5 \\
\hline Leucosolenia coriacea . & . c.c. & - & - & 27 & - & - & 1 & - & - & - & - & - \\
\hline Sycon coronatum & . indiv. & - & - & - & - & 1 & - & - & - & - & - & - \\
\hline Grantia compressa & . indiv. & 2 & 2 & 3 & 4 & 15 & - & 7 & - & - & 1 & 14 \\
\hline Leuconia nivea . & . c.c. & - & $\overline{-}$ & 3 & 3 & 5 & - & - & - & - & - & - \\
\hline Leuconia gossei . & . c.c. & - & - & - & $\overline{1}$ & $\frac{1}{2}$ & - & $\overline{-}$ & - & - & $\frac{1}{1}$ & $\overline{-}$ \\
\hline $\begin{array}{l}\text { Ute glabra } \\
\text { Halichondria panicea }\end{array}$ & . c.c. & $\overline{11}$ & $\overline{-}$ & $\overline{-}$ & & $1 \overline{0}$ & & $\overline{1}$ & $\overline{-}$ & $\overline{9}$ & $\overline{40}$ & $\bar{i}$ \\
\hline $\begin{array}{l}\text { Halichondria panicea } \\
\text { Halichondria albescens }\end{array}$ & . c.c. & 11 & $\overline{-}$ & $\overline{2}$ & 10 & 100 & $\overline{-}$ & 1 & - & - & - & $\frac{1}{2}$ \\
\hline Halichondria & & & & & & & & & & & 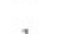 & \\
\hline $\begin{array}{l}\text { bowerbanki . } \\
\text { Hymeniacidon }\end{array}$ & . e.c. & - & - & - & - & - & - & - & - & - & 1 & - \\
\hline sanguinea & . c.c. & - & - & - & - & - & - & - & - & 4 & 5 & - \\
\hline Amphilectr & . c.c. & - & - & - & - & 3 & - & - & - & 1 & 4 & - \\
\hline & c.c. & - & - & - & - & 20 & - & - & - & - & - & \\
\hline Myxilla rosacea. & . c.c. & - & - & $\overline{-}$ & - & 2 & $25(\mathrm{c})$ & $\bar{z}$ & - & - & - & $\overline{-}$ \\
\hline Anchinöe fictitia & . e.c. & - & - & 5 & - & - & - & $25(\mathrm{c})$ & - & - & - & 15 \\
\hline Chalina cinerea . & . c.c. & - & - & - & - & - & - & - & - & - & 2 & - \\
\hline Myriothela cocksi & . indiv. & 1 & - & - & - & - & - & - & - & - & 3 & - \\
\hline Dynamena pumila . & . colony & - & - & - & - & - & - & - & - & 20 (c) & - & 25( \\
\hline Sertularella polyzonias & colony & - & - & - & 4 & $8(\mathrm{c}$ & - & - & 1 & - & - & 1 \\
\hline Sertularia operculata . & . colony & - & - & 1 & - & - & - & 10 & 45 (c) & - & 1 & 6 \\
\hline Kirchenpaueria pinnata & a colony & - & - & - & - & - & - & - & 18 & - & $=$ & - \\
\hline cea. & . colony & - & - & - & - & 4 & - & - & $10(\mathrm{c})$ & - & $5(c)$ & - \\
\hline Aglaophenia pluma & - plume & 1 & - & $40(c)$ & 1 & - & 24 & $250-300$ & - & 1 & - & - \\
\hline Metridium ? senile & . indiv. & $\bar{z}+x+a+x+3$ & - & - & $\bar{x}$ & $-\bar{\rho}$ & 1 (?) & - & - & - & - & $\overline{7}$ \\
\hline Corynactis viridis & . indiv. & 5 & - & 26 & 15 & 38 & 15 & - & - & - & - & 7 \\
\hline Erstedia dorsalis & . indiv. & - & - & - & - & - & - & - & - & - & - & 3 \\
\hline Erstedia nigra . & indiv. & 1 & - & 2 & - & - & 8 & - & - & - & - & - \\
\hline Lepidonotus clava & . indiv. & - & - & - & - & - & - & 1 & - & - & 1 & - \\
\hline Fon & . indiv. & - & - & - & - & - & $1(\mathrm{~s})$ & - & - & - & - & - \\
\hline Harmothöe impar & indiv. & - & - & 1 & - & - & $\overline{0}$ & - & $\overline{-}$ & $\overline{1}$ & $\overline{1}$ & $\overline{-}$ \\
\hline Harmothőe sp. & . indiv. & $\underline{z}$ & & - & 2 & 3 & 2 & $\overline{-}$ & $\overline{-}$ & 1 & 1 & $1(\bar{?})$ \\
\hline $\begin{array}{l}\text { Lagisca extenuata } \\
\text { Eulalia viridis }\end{array}$ & $\begin{array}{l}\text { indiv. } \\
\text { indiv. }\end{array}$ & $\overline{2}$ & $\overline{-}$ & - & $\overline{-}$ & $\overline{-}$ & $\overline{-}$ & $\overline{-}$ & $\overline{-}$ & $\overline{-}$ & $\overline{-}$ & $1(?)$ \\
\hline $\begin{array}{l}\text { Eulalia viridis } \\
\text { Eulalia sanguinea }\end{array}$ & $\begin{array}{l}\text { indiv. } \\
\text { indiv. }\end{array}$ & 1 & & $\overline{2}$ & $\overline{1}$ & $\overline{2}$ & 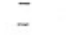 & $\overline{-}$ & $\overline{-}$ & $\overline{-}$ & 1 & $\overline{-}$ \\
\hline Eulalia sp. . & indiv. & - & - & $=$ & - & $=$ & - & - & - & - & 1 & - \\
\hline llis gracilis & indiv. & 1 & - & - & - & - & - & - & 1 & - & 1 & - \\
\hline llis ferrugina . & indiv. & - & - & 1 & - & - & - & - & $=$ & - & - & - \\
\hline prolifera & . indi & 1 & - & - & - & - & - & - & 1 & - & - & - \\
\hline Syllis variegata . & . indiv. & 4 & - & - & 1 & - & - & - & - & - & - & - \\
\hline Syllis armillaris . & . indiv. & - & 1 & 2 & - & - & 4 & - & - & - & - & - \\
\hline Syllis st & indiv. & - & 1 & $=$ & - & 1 & - & - & - & - & - & - \\
\hline isyllis zebra & indiv. & 2 & - & 1 & 2 & 1 & 1 & 2 & - & - & 1 & - \\
\hline lomstrandi . & . indi & 1 & - & 1 & - & - & - & - & 1 & - & - & - \\
\hline Grubea pusilla . & . indi & - & - & - & - & - & - & - & - & - & 1 & - \\
\hline Autolytus pictus & indiv. & - & - & 1 & - & - & - & - & - & - & - & - \\
\hline Autolytus sp. & indiv. & - & - & 2 & - & - & 1 & - & - & - & - & - \\
\hline. & indiv. & 2 & - & 1 & - & - & 4 & 1 & - & - & - & - \\
\hline aereis glauca & . indi & - & - & 1 & - & - & - & - & - & - & - & $\overline{-}$ \\
\hline Nereis pelagica . & . indiv. & 2 & - & 5 & $1(\mathrm{~s})$ & 7 & 5 & 2 & - & 1 & 11 & 5 \\
\hline Platynereis dumerili. & . indiv. & 11 & 1 & - & - & 5 & 1 & - & 1 (?) & - & 16 & 10 \\
\hline$\therefore$ & . indiv. & - & - & - & - & - & 1 & - & - & 2 & 1 & 2 \\
\hline netta. & . indiv. & 2 & - & 1 & 1 & 1 & 1 & - & - & 1 & 3 & 1 \\
\hline Eur & . indi & - & - & 1 & 1 & - & - & - & - & 1 & - & 1( \\
\hline Heterocirrus bioculatus & indiv. & 1 & - & - & - & - & - & - & - & - & - & - \\
\hline Arenicola sp. & . indiv. & $1(\mathrm{~s})$ & - & - & - & - & - & - & - & - & - & $\overline{1}$ \\
\hline Sabellaria spinulosa & indiv. & 9 & 2 & $1(?)$ & 1 & 1 & - & - & fr. (?) & 1 & - & 1 \\
\hline Nicolea zostericola & indiv. & $\bar{g}(\mathrm{~s})$ & - & 1 & - & - & - & - & - & - & - & - \\
\hline Sabella pavonina & . indiv. & $2(\mathrm{~s})$ & - & $3(?)(8)$ & - & $5(\mathrm{~s})$ & 1 (s) & $1(?)(\mathrm{s})$ & & - & $38(8)$ & - \\
\hline
\end{tabular}


Unit

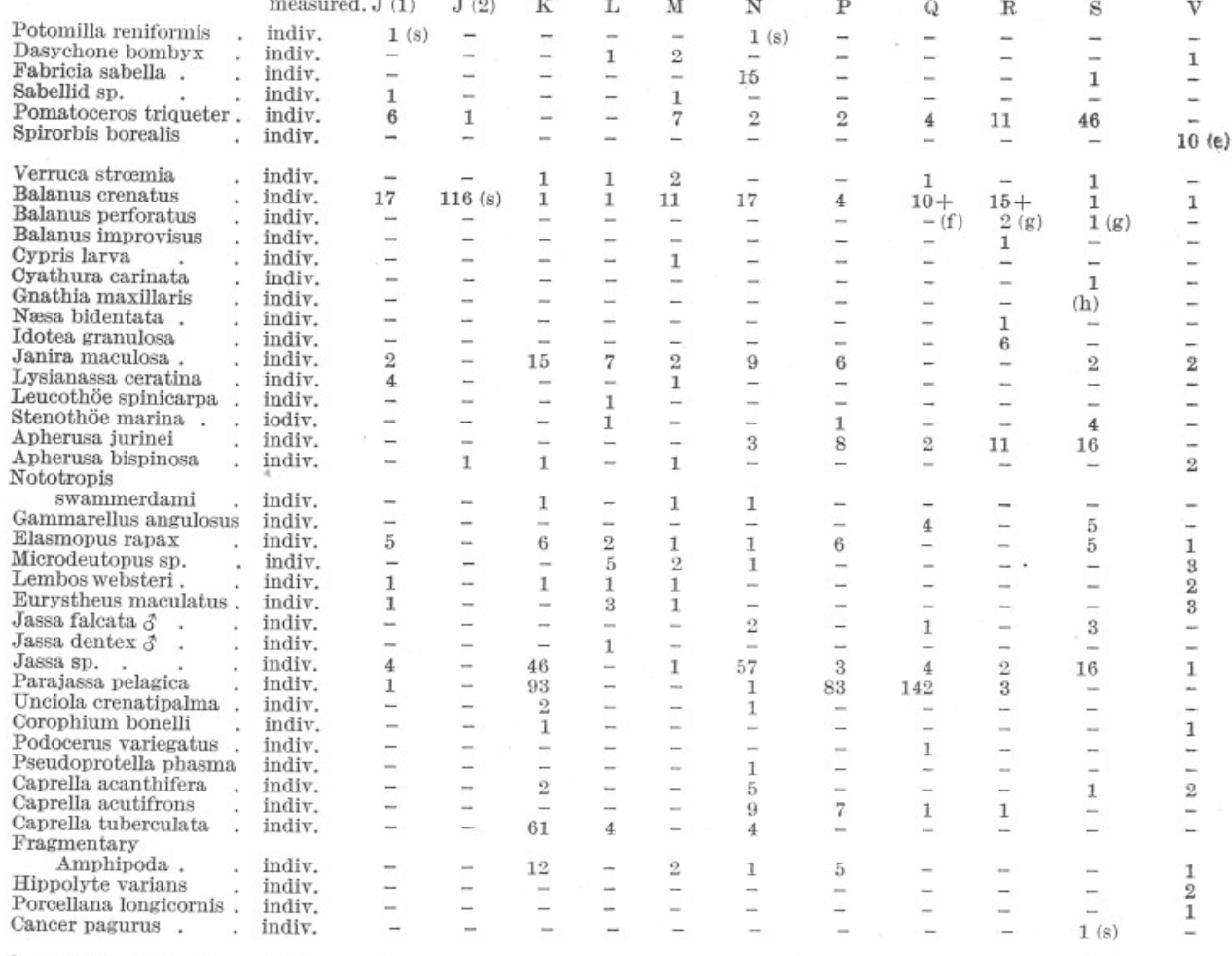

Pycnogonum littorale. indiv. Ammothea echinata : indiv.

Acanthochitona crinitus indiv.

Heteranomia squamula indiv.

Mytilus edulis (s) . indiv.

Musculus marmoratus . indiv.

Kellia suborbicularis : indiv.

Hiatella arctica. . indiv.

Patina pellucida . indiv.

Calliostoma zizyphinum indiv.

Littorina littoralis . indiv.

Littorina sp. . indiv.

Rissoa parva * . indiv.

Lamellaria perspicua . indiv.

$\begin{array}{lllllllllll}\text { Nassarius incrassatus: } & - & - & - & - & 1 & - & - & - & - & - \\ \text { Polycera quadrilineata: } & - & - & - & - & - & - & - & - & - & -\end{array}$

Scrupocellaria reptans. colony

Bugula turbinata: colony

Membranipora pilosa: sq. ins.

Umbonula verrucosa : sq. ins.

Schizoporella hyalina : sq.ins.

Schizoporella linearis :

Alcyonidium hirsutum

.

Ophiothrix fragilis
Amphipholis squamata
indiv.

Dendrodoa grossularia zooid

Distomus variolosus (n) zooid

Styelid sp.

Sidnyum turbinatum . colony

Amaroucium punctum

Amaroucium nordmanni colony

$\begin{array}{lll}\text { Aplidium pallidum } & \text { colony } \\ \text { Morchellium argus } & \text { colony }\end{array}$

Diplosoma listerianum sq. ins.

Trididemnum tenerum.

Didemnid sp. 
